\title{
Nutritional and energetic value of rice by-products, with or without phytase, for growing pigs
}

\author{
Valor nutricional e energético de sub-produtos do arroz, com ou sem \\ fitase, para suínos em crescimento
}

\begin{abstract}
Julio Cezar Dadalt ${ }^{\mathrm{I}}$ Andréa Machado Leal Ribeiro ${ }^{\mathrm{II}}$ Alexandre de Mello Kessler ${ }^{\mathrm{II}}$ William Rui Wesendonck ${ }^{I I}$ Luciane Bockor ${ }^{\text {II }}$ Gilson Alexandre Gomes ${ }^{\text {III }}$
\end{abstract}

\section{ABSTRACT}

The objective of this study was to evaluate nutritional and energetic value of rice by-products, with or without phytase, using growing pigs. Thirty-six male pigs were housed in individual metabolic cages. Total collection of feces and urine was carried out in two periods of ten days: five days for adaptation and five days for collection. A randomized blocks design was used, considering the sampling period as a block, with five treatments and seven replicates. Two control diets (with and without phytase - Phy) were used in the digestibility calculations, the latter in order to evaluate the enzyme influence on energy digestibility of the tested ingredients. The control diet was replaced by $30 \%$ of one of the ingredients: defatted rice bran (DRB) with and without Phy and dephytinised defatted rice bran (DDRB). The use of Phy in the control diet did not influence $D R B+P$ hy energy digestibility. Relative to $D R B+P h y$, dephytinised defatted rice bran had higher contents of $M E$ and digestible protein but lower digestible $P$ and $C a$. Phy supplementation increased $C a$ and $P$ utilization of DRB and improved energy and protein digestibility. The DRB without Phy showed the lowest digestibility coefficients for all responses. Metabolizable energy, digestible protein, phosphorus and calcium of $D R B, D R B+P h y$ and $D D R B$ were respectively, 2140, 2288 and

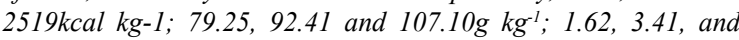
$2.11 \mathrm{~g} \mathrm{~kg}^{-1}$ and 2.80, 3.79 and $2.90 \mathrm{~g} \mathrm{~kg}^{-1}$.

Key words: alternative ingredients, dephytinization, enzyme, nutrients.

\section{RESUMO}

O objetivo do presente trabalho foi avaliar o valor nutricional e energético de subprodutos do arroz, na presença ou não de fitase, para suínos em crescimento. Foram utilizados 36 suínos machos, castrados, alojados em gaiolas metabólicas individuais. Realizou-se a coleta total de fezes e urina em dois periodos de dez dias: cinco de adaptação e cinco de coleta. Utilizouse o delineamento de blocos ao acaso, tendo-se considerado o período de coleta como bloco, com cinco tratamentos e sete repetições. Duas dietas controle (com e sem fitase - Fit) foram utilizadas nos cálculos de digestibilidade, a última para avaliar a influência da enzima na digestibilidade da energia dos ingredientes teste. A dieta controle foi substituída em $30 \%$ pelos subprodutos testados: farelo de arroz desengordurado (FAD) com ou sem Fit e farelo de arroz desengordurado desfitinizado (FADD). O uso de fitase na dieta controle não influenciou na digestibilidade da energia do FAD +Fit. Comparado ao FAD +Fit, o farelo de arroz desengordurado desfitinizado apresentou mais EM e proteina digestivel, mas menos $P$ e Ca digestiveis. A suplementação de fitase melhorou a utilização do P e Ca do FAD e aumentou a digestibilidade da energia e da proteina. O FAD sem fitase apresentou os menores coeficientes de digestibilidade para todas as respostas. Energia metabolizável, proteína, fósforo e cálcio digestiveis do FAD, FAD +Fit e FADD foram, respectivamente, 2.140; 2.288 e $2.519 \mathrm{kcal} \mathrm{kg}^{-1} ; 79,25 ; 92,41$ e 107,10g kg-1; 1,62; 3,41 e 2,11g $\mathrm{kg}^{-1}$ e 2,80; 3,79 e 2,90g $\mathrm{kg}^{-1}$.

Palavras-chave: desfitinização, enzima, ingredientes alternativos, nutrientes.

\section{INTRODUCTION}

Grain-based diets contain enough total $\mathrm{P}$ to meet the requirements of pigs. However, 60 to $80 \%$ of $\mathrm{P}$ is in the form of phytate (SELLE et al., 2011); hence, the bioavailability of this $P$ is low in pigs. Defatted rice bran contains high levels of crude protein $(15.3 \%)$ and $\mathrm{P}(1.89 \%)$ (ROSTAGNO

\footnotetext{
IDepartamento de Nutrição e Produção Animal, Universidade de São Paulo (USP), 13635-900, Pirassununga, SP, Brasil. E-mail: julio@zootecnista.com.br. Corresponding author.

IIFaculdade de Agronomia, Universidade Federal do Rio Grande do Sul (UFRGS), Porto Alegre, RS, Brasil.

IIIAB Vista Feed Ingredients, 3 Woodstock Court, Marlborough Business Park, Wilts, SN8 4AN, United Kingdom. Received 08.21.14 Approved 10.30.14 Returned by the author 02.24.15 CR-2014-1240.R1
} 
et al., 2011). However, about $85 \%$ of the total $\mathrm{P}$ is unavailable to non-ruminant animals as it is bound up in phytate (ROSTAGNO et al., 2011). This impairs $\mathrm{P}$ absorption by pigs and facilitates chelation with other minerals. Previous research by HASTAD et al. (2005) determined that some varieties of low-phytate corn had a greater energy content compared with conventional varieties.

The use of phytase (Phy) to increase the use of phytic acid is already known in the monogastric feed industry. Phytase catalyzes the hydrolytic degradation of phytic acid (myo-inositol hexaphosphate) and its salts (phytate), resulting in inositol, inositol monophosphate and inorganic phosphate (MULLANEY et al., 2000). According to LIAO et al. (2002), phytate may decrease starch digestibility by several mechanisms. Supplementation of phytase may release starch and $\alpha$-amylase, thereby increasing the digestible energy content of the diets.

Besides the use of phytase, phytic acid removal from vegetable ingredients through industrial processes and/or laboratory methods have been employed successfully by SERVI et al. (2008) and CANAN et al. (2011). The removal of phytic acid from rice bran through these techniques aims to produce, as the main product, phytate, and generate as a by-product dephytinised defatted rice bran. Phytate is used in cosmetics and in the pharmaceutical industry, to help prevent certain human diseases such as diabetes (LEE et al., 2006) and kidney stones (SAW et al., 2007), and in the food industry to inhibit oxidative peroxidation (LEE \& HENDRICKS et al., 1995). Nevertheless, dephytinised rice bran can be used in the feed industry, and may have higher nutrient availability because of its low content of phytate phosphorus. The aim of this study was to evaluate nutritional and energetic value of rice-by products, with or without phytase, using growing pigs.

\section{MATERIAL AND METHODS}

Thirty-six crossbred barrows were used (PIC sire and female DB-DanBred). The experiment was conducted in metabolic cages and divided into two periods of 10 consecutive days, with 5 days of adaptation and 5 days of total feces and urine collection. Pigs weighed $29 \pm 0.73 \mathrm{~kg}$ and $37 \pm 0.55 \mathrm{~kg}$ at the beginning of the first and second period, respectively.

The dephytinisation process consisted of maceration of the defatted rice bran (DRB), solubilizing the bran in an aqueous solution followed by acidification of the solution. The methodology was developed by the Federal University of Santa Maria and a private company $\left(\mathrm{INGAL}^{\circledR}\right)$. The same source of DRB used to feed the animals was used for the dephytinisation process.

A randomized blocks design was used, considering the sampling period as a block, with five treatments and seven replicates. The experimental unit was the pig. The treatments were: (CONT) Control diet (ground corn and soybean meal); (CONT+Phy) Control diet with $100 \mathrm{mg} \mathrm{kg}^{-1}$ phytase; (CONT+DRB) $700 \mathrm{~g} \mathrm{~kg}^{-1}$ Control diet and $300 \mathrm{~g} \mathrm{~kg}^{-1}$ DRB (defatted rice bran); (CONT+DRB+Phy) $700 \mathrm{~g}$ $\mathrm{kg}^{-1}$ Control diet, $300 \mathrm{~g} \mathrm{~kg}^{-1} \mathrm{DRB}$ and $200 \mathrm{mg} \mathrm{kg}^{-1}$ phytase; (CONT+DDRB) $700 \mathrm{~g} \mathrm{~kg}^{-1}$ Control diet, $300 \mathrm{~g} \mathrm{~kg}^{-1}$ dephytinised defatted rice bran. The control diet with phytase was introduced because phytase could affect the reference diet, delivering nutrients that could be attributed erroneously to DRB.

The enzyme used was Quantum Blue ${ }^{\circledR}$, an enhanced 6-phytase from Escherichia coli and with an activity of $6,800 \mathrm{FTU} \mathrm{g}^{-1}$. The digestibility of the DRB, DRB+Phy and DDRD were calculated by the difference (indirect) approach (ADEOLA, 2001).

Pigs received water ad libitum and the amount of feed, distributed in two daily meals $9 \mathrm{~h}$ and $17 \mathrm{~h}$, was adjusted to give an energy consumption of 2.6 times maintenance, estimated as $250 \mathrm{kcal} \mathrm{kg}^{-1}$ $\mathrm{EM} \times \mathrm{LW}^{0.60}$ (NOBLET \& SHI, 1993). The Control diet was formulated according to the nutritional recommendations proposed by ROSTAGNO et al. (2011) (Table 1) for growing pigs. Rice bran was included in the diet by a difference (indirect) approach, wherein $300 \mathrm{~g} \mathrm{~kg}^{-1}$ of the control diet on a dry matter basis was replaced with the test ingredients.

Total feces and urine were collected, and the beginning and end of each collection determined by the appearance of marked feces with the addition of $0.25 \%$ of ferric oxide $\left(\mathrm{Fe}_{2} \mathrm{O}_{3}\right)$ in the diets. Feces were collected twice a day (10h and $18 \mathrm{~h})$, weighed, packed in plastic bags and stored in a freezer at $-10^{\circ} \mathrm{C}$. At the end of the experiment, the feces were homogenized and sampled $\left(300 \mathrm{~g} \mathrm{~kg}^{-1}\right)$, dried in a forced air oven at $60^{\circ} \mathrm{C}$ for 72 hours, and ground for later analysis. Urine was collected in plastic buckets together with $5 \mathrm{ml} \mathrm{H}_{2} \mathrm{SO}_{4}$. The volume was weighed daily, and a $10 \%$ aliquot was removed and refrigerated at $-10^{\circ} \mathrm{C}$.

Diet, defatted and dephytinised rice bran and feces samples were ground in a knife mill with a one millimeter sieve, and analyzed for dry matter, crude protein, phosphorus and calcium. Gross energy was analyzed by bomb calorimetry (model C2000 - IKA Werke GmbH and Co. KG, Staufen, 
Table 1 - Diet formulation and nutrient content of the control diet (CONT), defatted rice bran (DRB) and dephytinised defatted rice bran (DDRB).

\begin{tabular}{|c|c|c|c|}
\hline Ingredients (\%) & CONT & & \\
\hline Corn & 70.10 & & \\
\hline Soybean meal $44 \mathrm{CP}$ & 24.20 & & \\
\hline Soybean oil & 2.00 & & \\
\hline Limestone & 1.40 & & \\
\hline Dicalcium phosphate & 1.20 & & \\
\hline Salt & 0.50 & & \\
\hline L-Lysine $\mathrm{HCl}(78 \%)$ & 0.16 & & \\
\hline DL-Methionine & 0.23 & & \\
\hline Ethoxiquin & 0.03 & & \\
\hline Choline $\mathrm{Cl}(60 \%)$ & 0.07 & & \\
\hline Vitamin premix* & 0.04 & & \\
\hline Mineral premix $* *$ & 0.07 & & \\
\hline $\begin{array}{l}\text { Calculated and analyzed } \\
\text { composition }\end{array}$ & CONT & DRB & DDRB \\
\hline Dry matter $(\%)^{1}$ & 88.10 & 87.70 & 87.70 \\
\hline Crude protein $(\%)^{1}$ & 17.00 & 15.30 & 16.30 \\
\hline Digestible lysine $(\%)^{1}$ & 0.89 & - & - \\
\hline Digestible methionine $(\%)^{1}$ & 0.28 & - & - \\
\hline Met + cys $(\%)^{1}$ & 0.53 & - & - \\
\hline Total calcium $(\%)^{2}$ & 0.84 & 0.07 & 0.04 \\
\hline Total phosphorus $(\%)^{2}$ & 0.49 & 2.68 & 1.17 \\
\hline Phytate $(\%)^{3}$ & 0.24 & 2.16 & 0.94 \\
\hline Sodium $(\%)^{1}$ & 0.20 & - & - \\
\hline $\operatorname{Ash}(\%)^{2}$ & 0.50 & - & - \\
\hline Ether extract $(\%)^{2}$ & 4.80 & - & - \\
\hline $\operatorname{Starch}(\%)^{2}$ & - & 47.8 & 50.00 \\
\hline Gross energy $\left(\mathrm{kcal} \mathrm{kg}^{-1}\right)^{2}$ & 3,953 & 3,494 & 3,771 \\
\hline
\end{tabular}

*Vitamin premix provided the following per kilogram of diet: Vitamin A, 11,200IU; Vitamin D3, 2,100IU; Vitamin E, 25.2mg; Vitamin K, 2.8mg; Vitamin B1, 2.24mg; Vitamin B2, 7.14mg;

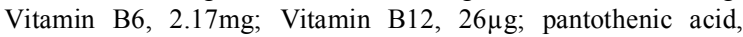
$18.2 \mathrm{mg}$; niacin, $36.4 \mathrm{mg}$; folic acid, $0.63 \mathrm{mg}$; Biotin, $126 \mathrm{mcg}$.

**Mineral premix provided the following per kilogram of diet: Se, 0.39mg; I, 0.46mg; Fe, 52mg; Cu, 10.4mg; Zn, 104mg; Mn, $39 \mathrm{mg}$.

${ }^{1}$ Calculated data.

${ }^{2}$ Analyzed data.

${ }^{3}$ Date were calculated according to NRC (2012).

Germany). Urine samples from each animal were dried in a forced air oven at $60^{\circ} \mathrm{C}$ for 72 hours, and also analyzed for gross energy.

Determination of the coefficients of digestibility (CD) of dry matter (CDDM), gross energy (CDGE), crude protein (CDCP), calcium and phosphorus for the diets and ingredients were calculated. The values of digestible protein (DP) in the defatted and dephytinised rice bran were determined according to SAKOMURA \& ROSTAGNO (2007). To calculate DE and ME of the ingredients, CAMPBELL et al. (1983) formula was used. From this calculation, the energy values of the two control diets, CONT and CONT+Phy were compared.

Data were analyzed in a completely randomized design, considering the period as a block, by ANOVA and LS Means using the GLM procedure (Statistical Analysis System, version 9.2). Pooled SEM was calculated by averaging the SEM calculated by the GLM procedure of SAS for the variable of interest. A level of $\mathrm{P}<0.05$ was defined as indicating statistical significance.

\section{RESULTS AND DISCUSSION}

In the comparison of the two control diets (with and without Phy), there was no difference in the energy values obtained, independently of the use of phytase. Thus, all other calculations were developed using the control diet without phytase.

Dry matter intake was similar for all treatments, as expected since feed was provided in accordance with metabolic weight and the pigs had similar body weights (Table 2). The coefficients of digestibility of dry matter, gross energy, crude protein, $\mathrm{Ca}, \mathrm{P}$, as well as $\mathrm{DE}$ and $\mathrm{ME}$ of the two control diets were high compared to the other diets. This result is consistent, since the control diets had adequate nutritional balance in their formulations and less fiber due to the absence of rice bran (Table 1). However, CONT + Phy showed a higher P digestibility. Dietary starch and fiber are important nutrients for pigs but are underappreciated in their complexity (REGMI et al., 2011). Increasing rice bran levels in growing and finishing pig diets had a linear effect on nutrients digestibility (KUNRATH et al., 2010), related to the increase in fiber content, since increasing dietary fiber increases the rate of digesta passage (PARTANEN et al., 2007) and negatively affects the digestibility of many nutrients, even fiber itself (GOMES et al., 2007).

The addition of phytase to the diet with rice bran not only improved the use of $\mathrm{Ca}$ and $P$, an effect that is already well known in the literature (OMOGBENIGNUN et al., 2003), but also improved digestibility of dry matter, energy and protein, similar to the findings of ZANELLA et al. (1999). The diet with dephytinised DRB had lower dry matter digestibility than the diet with DRB + Phy, but similar gross energy and crude protein digestibility. The DE and ME of the diet with dephytinised DRB were higher compared to rice bran-containing diets. For the DDRB diet, $\mathrm{Ca}$ and $\mathrm{P}$ digestibility were lower than those for the 
Table 2 - Dry matter intake, coefficients of digestibility of the control diet (CONT), CONT + phytase $($ CONT + Phy), CONT + defatted rice bran $(\mathrm{CONT}+\mathrm{DRB}), \mathrm{CONT}+\mathrm{DRB}+$ Phy and $\mathrm{CONT}+$ dephytinised defatted rice bran $(\mathrm{CONT}+\mathrm{DDRB})$ in growing pigs.

\begin{tabular}{|c|c|c|c|c|c|c|c|}
\hline \multirow[t]{2}{*}{ Dry matter intake $\left(\mathrm{g} \mathrm{day}^{-1}\right)$} & \multirow{2}{*}{$\begin{array}{l}\text { CONT }^{*} \\
1.55\end{array}$} & \multirow{2}{*}{$\begin{array}{c}\text { CONT }+ \text { Phy } \\
1.55 \\
\end{array}$} & \multirow{2}{*}{$\begin{array}{l}\text { CONT+ } \\
\text { DRB } \\
1.58 \\
\end{array}$} & \multirow{2}{*}{$\begin{array}{l}\text { CONT+ } \\
\text { DRB+ Phy } \\
1.54\end{array}$} & \multirow{2}{*}{$\begin{array}{l}\text { CONT+ } \\
\text { DDRB } \\
1.54 \\
\end{array}$} & \multirow{2}{*}{$\begin{array}{l}\mathrm{P} \\
0.5\end{array}$} & \multirow{2}{*}{$\begin{array}{l}\text { SEM** } \\
0.001\end{array}$} \\
\hline & & & & & & & \\
\hline & & Apparent dig & bility----- & & & & \\
\hline Dry matter (\%) & $87.3^{\mathrm{a}}$ & $87.4^{\mathrm{a}}$ & $77.5^{\mathrm{d}}$ & $80.1^{\mathrm{b}}$ & $78.8^{\mathrm{c}}$ & $<0.001$ & 0.004 \\
\hline Gross energy (\%) & $88.4^{\mathrm{a}}$ & $88.1^{\mathrm{a}}$ & $81.3^{\mathrm{c}}$ & $82.6^{\mathrm{b}}$ & $81.8^{\mathrm{bc}}$ & $<0.001$ & 0.003 \\
\hline Crude protein $(\%)$ & $85.2^{\mathrm{a}}$ & $84.9^{\mathrm{a}}$ & $74.4^{\mathrm{c}}$ & $77.7^{\mathrm{b}}$ & $78.3^{\mathrm{b}}$ & $<0.001$ & 0.007 \\
\hline Calcium (\%) & $65.1^{\mathrm{a}}$ & $68.2^{\mathrm{a}}$ & $41.1^{\mathrm{c}}$ & $55.7^{\mathrm{b}}$ & $44.4^{\mathrm{c}}$ & $<0.001$ & 0.014 \\
\hline Phosphorus (\%) & $47.1^{\mathrm{b}}$ & $56.0^{\mathrm{a}}$ & $15.1^{\mathrm{e}}$ & $34.4^{\mathrm{c}}$ & $28.9^{\mathrm{d}}$ & $<0.001$ & 0.019 \\
\hline $\mathrm{DE}\left(\mathrm{kcal} \mathrm{kg}^{-1}\right)$ & $3,493^{\mathrm{a}}$ & $3,470^{\mathrm{a}}$ & $3,121^{\mathrm{d}}$ & $3,183^{\mathrm{c}}$ & $3,229^{b}$ & $<0.001$ & 0.172 \\
\hline $\operatorname{ME}\left(\mathrm{kcal} \mathrm{kg}^{-1}\right)$ & $3,407^{\mathrm{a}}$ & $3,386^{\mathrm{a}}$ & $3,041^{\mathrm{d}}$ & $3,095^{\mathrm{c}}$ & $3,181^{\mathrm{b}}$ & $<0.024$ & 0.188 \\
\hline
\end{tabular}

Means sharing the same letters in rows did not differ for the LS-Means $(\mathrm{P}>0.05)$.

*Data represents the average of seven replicates, except for CONT+DRB+Phy, which had eight replicates.

**Standard error of mean.

DRB without Phy. The DRB diet generally had the lowest nutrient digestibilities.

Regarding the digestibility of the test ingredients (Table 3), control diet of dry matter, gross energy and crude protein were higher for DRB+Phy and Dephytinised DRB than DRB. These values agree with those obtained by NAMKUNG \& LEESON (1999), in which the use of phytase increased energy, minerals, and amino acid availability in the diet of broilers. In the present study, the dephytinisation process had similar effect to the use of phytase enzyme in the animal.

The digestible protein (DP) of rice bran in this study was lower than that found by
ROSTAGNO et al. (2011) (79.3 vs $114.1 \mathrm{~g} \mathrm{~kg}^{-1}$ ), although similar values for crude protein content were noted (15.3 and $15.5 \%$, respectively). A low crude protein digestibility (56.6\%) was also observed by KUNRATH et al. (2010), and is close to the value seen in this experiment $(51.8 \%)$, and lower than the values suggested by ROSTAGNO et al. (2011; $74.6 \%$ ). These variations may be associated with intrinsic and/or extrinsic ingredient characteristics, such as source and processing. In the two cases cited as having low digestibility, the rice bran was from the south of Brazil. The type of rice processing can also influence the chemical composition of the bran (DENARDIN et al., 2004).

Table 3 - Coefficients of digestibility of the ingredients defatted rice bran (DRB), defatted rice bran + phytase (DRB + Phy) and dephytinised defatted rice bran (DDRB) in growing pigs.

\begin{tabular}{|c|c|c|c|c|c|}
\hline & \multicolumn{3}{|c|}{--------------------------Ingrediets------------------------' } & \multirow{2}{*}{$\mathrm{P}$} & \multirow{2}{*}{ SEM** } \\
\hline & $\mathrm{DRB}^{*}$ & DRB + Phy & DDRB & & \\
\hline & & & & & \\
\hline Dry matter (\%) & $54.7^{\circ}$ & $63.3^{\mathrm{a}}$ & $60.6^{\mathrm{a}}$ & $<0.003$ & 0.016 \\
\hline Gross energy $(\%)$ & $62.4^{\mathrm{b}}$ & $67.1^{\mathrm{a}}$ & $69.0^{\mathrm{a}}$ & $<0.020$ & 0.020 \\
\hline Crude protein $(\%)$ & $51.8^{\mathrm{b}}$ & $60.4^{\mathrm{a}}$ & $65.7^{\mathrm{a}}$ & $<0.003$ & 0.023 \\
\hline Calcium (\%) & $-0.5^{b}$ & $-0.2^{\mathrm{a}}$ & $-0.4^{\mathrm{b}}$ & $<0.001$ & 0.000 \\
\hline Phosphorus (\%) & $-0.1^{\mathrm{c}}$ & $0.5^{\mathrm{a}}$ & $0.05^{\mathrm{b}}$ & $<0.001$ & 0.001 \\
\hline Digestible $\mathrm{Ca}\left(\mathrm{g} \mathrm{kg}^{-1}\right)$ & $2.80^{\mathrm{b}}$ & $3.79^{\mathrm{a}}$ & $2.90^{\mathrm{b}}$ & $<0.001$ & 0.000 \\
\hline Digestible P $\left(\mathrm{g} \mathrm{kg}^{-1}\right)$ & $1.62^{b}$ & $3.41^{\mathrm{a}}$ & $2.11^{\mathrm{b}}$ & $<0.001$ & 0.000 \\
\hline Digestible protein $\left(\mathrm{g} \mathrm{kg}^{-1}\right)$ & $79.25^{\mathrm{c}}$ & $92.41^{b}$ & $107.10^{\mathrm{a}}$ & $<0.001$ & 0.004 \\
\hline Digestible energy $\left(\mathrm{kcal} \mathrm{kg}^{-1}\right)$ & $2,181^{\mathrm{c}}$ & $2,343^{b}$ & $2,545^{\mathrm{a}}$ & $<0.001$ & 0.046 \\
\hline Metabolizable energy ( $\mathrm{kcal} \mathrm{kg}^{-1}$ ) & $2,140^{\mathrm{c}}$ & $2,288^{b}$ & $2,519^{\mathrm{a}}$ & $<0.001$ & 0.049 \\
\hline
\end{tabular}

Means followed by same letters in rows did not differ for the LS-Means $(\mathrm{P}>0.05)$.

*Data represents the average of seven replicates, except for DRB+Phy, which had eight replicates.

**Standard error of mean. 
The $\mathrm{Ca}$ and $\mathrm{P}$ digestibility was greater for $\mathrm{DRB}+\mathrm{Phy}$ than for DRB. The phytase enzyme has proven to be successful for degrading phytic acid in the gastrointestinal tract of pigs, with increases in the amounts of calcium and phosphorus available, a response that confirms the results in table 2 and is in agreement with TRUJILLO \& LINDEMANN (2010). The negative values seen in this experiment for $\mathrm{Ca}$ and $\mathrm{P}$ digestibility may be associated with the high level of complexed $\mathrm{P}$ in rice bran and endogenous $\mathrm{Ca}$ and $\mathrm{P}$. The antinutritive properties of phytate include forming complexes with amino acids, inhibiting porcine proteolytic enzymes, and increasing endogenous amino acid secretions, thereby reducing apparent amino acids digestibility and decreasing availability of $\mathrm{P}, \mathrm{Ca}$, and other divalent minerals (SELLE \& RAVINDRAN, 2008).

The reduced coefficients of digestibility of $\mathrm{Ca}$ and $\mathrm{P}$ in Dephytinised rice bran compared to DRB+Phy may be associated with high amounts of phytic acid still remaining in the former after the dephytinisation process. The rice bran and Dephytinised rice bran had 2.68 and $1.17 \%$ of total phosphorus, respectively (Table 1), showing that $44 \%$ of the total phosphorus remained in the dephytinised bran. According to SERVI et al. (2008), reduction of phytic acid by more than $90 \%$ could significantly improve bioavailability and absorption of minerals and proteins. Since dephytinisation did not remove all $\mathrm{P}$, one can assume that some of remaining phosphorus was in the form of phytate, and supplementation with phytase could be positive. The dephytinised rice bran showed the highest values of digestible protein, $\mathrm{DE}$ and $\mathrm{ME}(\mathrm{P}<0.001)$, compared to rice bran independently of the use of phytase. The higher crude protein and gross energy found in Dephytinised, compared to rice bran $\left(16.3 \%\right.$ and $3,771 \mathrm{kcal} \mathrm{kg}^{-1}$ vs. $15.3 \%$ and $3,494 \mathrm{kcal}$ $\mathrm{kg}^{-1}$, respectively, Table 1), and the slightly higher amount of starch (50.0 vs $47.8 \%$ ) explain the higher DE values of DDRB. According to HURRELL (2004), removing phytic acid facilitates ingredient digestion because it prevents the chelation of myoinositol hexaphosphate molecules with multivalent metal ions, especially zinc and calcium. Phytate also binds with proteins, amino acids, starch and enzymes such pepsin, trypsin and alpha amylase, compromising digestion and absorption (CASEY $\&$ WALSH, 2004). The low nutrient digestibility observed with DRB compared to DRB+Phy was also observed by SILVA et al. (2005), when phytase supplementation improved the apparent ileal digestibility of amino acids from defatted rice bran and soybean meal in growing pigs.

\section{CONCLUSION}

The dephytinization process and phytase addition improved the nutrient digestibility of defatted rice bran. Metabolizable energy, digestible protein, phosphorus and calcium of DRB, DRB+Phy and DDRB were respectively, 2,140; 2,288 and 2,519kcal $\mathrm{kg}^{-1} ; 79.25 ; 92.41$ and $107.10 \mathrm{~g} \mathrm{~kg}^{-1} ; 1.62 ; 3.41$, and $2.11 \mathrm{~g} \mathrm{~kg}^{-1}$ and $2.80 ; 3.79$ and $2.90 \mathrm{~g} \mathrm{~kg}^{-1}$.

\section{ACKNOWLEDGEMENTS}

The authors gratefully acknowledge the scholarship for this project from Conselho Nacional de Desenvolvimento Científico e Tecnológico (CNPq).

\section{ETHICS AND ANIMAL EXPERIMENTATION COMMITTEE}

All research methods approved by the ethics and animal experimentation committee at the Federal University of Rio Grande do Sul (project 20908), and followed all the requirements in relation to animal welfare.

\section{REFERENCES}

CAMPBELL, G.L. et al. Calculation of metabolizable energy for ingredients incorporated at low levels into a reference diet. Poultry of Animal Science, v.62, p.705-707, 1983. Available from: $<$ http:// ps.oxfordjournals.org/content/62/4/705.short>. Accessed: Feb. 22, 2014. doi: $10.3382 / \mathrm{ps} .0620705$

CANAN, C. et al. Studies on the extraction and purification of phytic acid from rice bran. Journal of Food Composition e Analysis, v.24, p.1057-1063, 2011. Available from: <http://www. sciencedirect.com/science/article/pii/S0889157511000317>. Accessed: Feb. 10, 2014. doi: 10.1016/j.jfca.2010.12.014.

CASEY, A.; WALSH, G. Identification and characterization of a phytase of potential commercial interest. Journal of Biotechnology, v.110, p.313-322, 2004. Available from: <http:// www.sciencedirect.com/science/article/pii/S0168165604001567>. Accessed: Feb. 26, 2014. doi: 10.1016/j.jbiotec.2004.03.001.

DENARDIN, C.C. et al. Composição mineral de cultivares de arroz integral, parbolizado e branco. Alimentos e Nutrição, v.15, p125-130, 2004. Available from: $<$ http://serv-bib.fcfar.unesp.br/seer/index.php/ alimentos/article/viewFile/66/81>. Accessed: Feb. 22, 2014.

GOMES, J.D.F. et al. Efeitos do incremento de fibra dietética sobre a digestibilidade, desempenho e características de carcaça: suínos em crescimento e terminação. Ciências Agrárias, v.28, p.483-492, 2007. Available from: $<$ http://dx.doi.org/10.5433/16790359.2007v28n3p483>. Accessed: Dec. 06, 2013.

HASTAD, C.W. et al. Comparison of yellow dent and NutriDense corn hybrids in swine diets. Journal of Animal 
Science, v.83, p.2624-2631, 2005. Available from: <http:// www.journalofanimalscience.org/content/83/11/2624.full.pdf>. Accessed: Mar. 13,2014. doi: 10.2527/jas.2007-0594.

HURRELL, R.F. Phytic acid degradation as a means of improving iron absorption. International Journal for Vitamin and Nutritional Research, v.74, p.445-452, 2004. Available from: <http://www. medcontent.metapress.com/content/b164379r1|747088>. Accessed: Feb. 05, 2014. doi: 10.1024/0300-9831.74.6.445.

KUNRATH, M.A. et al. Metodologias de avaliação do valor nutricional do farelo de arroz desengordurado para suínos. Pesquisa Agropecuária Brasileira, v.45, p.1172-1179, 2010. Available from: <http://dx.doi.org/10.1590/S0100-204X2010001000017>. Accessed: Feb. 10, 2014.

LEE, B.J.; HENDRICKS, D.G. Phytic acid protective effect beef round muscle lipid peroxidation. Journal of Food Science, v.60, p.241-244, 1995. Available from: <http://onlinelibrary.wiley. com/doi/10.1111/j.1365-2621.1995.tb05646.x/pdf>. Accessed: Feb. 27, 2014.

LEE, S.H. et al. Dietary phytic acid lowers the blood glucose level in diabetic KK mice. Nutritional Research, v.26, p.474-479, 2006. Available from: <http://www.sciencedirect.com/science/ article/pii/S0271531706001199>. Accessed: Apr. 14, 2014. doi: 10.1016/j.nutres.2006.06.017.

LIAO, S.F. et al. Supplementation of microbial phytase to swine diets: effects on utilization of nutrients. In: NAKANO, T.; OZIMEK, L. (Eds). Food science and product technology. Kerala, India: Research Signpost, 2002. p.199-227.

MULLANEY, E.J. et al. Advances in phytase research. Advances in Applied Microbiology, v.47, p.157-199, 2000. Available from: <http:// www.sciencedirect.com/science/article/pii/S0065216400470048>. Accessed: Mar. 12, 2014. doi: 10.1016/S0065-2164(00)47004-8.

NAMKUNG, H.; LEESON, S. Effect of phytase enzyme on dietary nitrogen-corrected apparent metabolizable energy and ileal digestibility of nitrogen and amino acids in broiler chicks. Poultry Science, v.78, p.1317-1319, 1999. Available from: <http:// ps.oxfordjournals.org/content/78/9/1317.long $>$. Accessed: Apr. 12, 2014. doi: $10.1093 / \mathrm{ps} / 78.9 .1317$.

NOBLET, J.; SHI, X.S. Comparative digestibility of energy and nutrients in growing pigs fed ad libitum and adult sows fed at maintenance. Livestock Production Science, v.34, p.137-152, 1993. Available from: <http://www.sciencedirect.com/science/ article/pii/030162269390042G>. Accessed: Apr. 25, 2014. doi: 10.1016/0301-6226(93)90042-G.

OMOGBENIGNUN, F.O. et al. The effect of supplementing microbial phytase and organic acid to a corn-soybean based diet fed to early-weaned pigs. Journal of Animal Science, v.8, p.18061813, 2003. Available from: <http://www.journalofanimalscience. org/\%20content/81/7/1806.full.pdf $>$. Accessed: May 02, 2014. doi: 10.1111/j.1740-0929.2008. 00590.x.

PARTANEN, K. et al. Effects of a dietary organic acid mixture and of dietary fibre levels on ileal and faecal nutrient apparent digestibility, bacterial nitrogen flow, microbial metabolite concentrations and rate of passage in the digestive tract of pigs. Animal, v.1, p.389-401, 2007. Available from:
$<$ http://journals.cambridge.org/action/displayAbstract?\%20fr omPage $=$ online $\&$ aid $=964340 \&$ file $I d=S 1751731107657838>$. Accessed: May 02, 2014.

REGMI, P.R. et al. Starch with high amylose and low in vitro digestibility increases intestinal nutrient flow and microbial fermentation and selectively promotes bifidobacteria in pigs. Journal of Nutrition, v.141, p.1273-1280, 2011. Available from: $<$ http://jn.nutrition.org/content/early/2011/05/31/jn.111.140509. full.pdf $>$. Accessed: Feb. 06, 2014. doi: 10.3945/jn.111.140509.

ROSTAGNO, H.S. et al. Tabelas brasileiras para aves e suínos: composição de alimentos e exigências nutricionais, 3.ed. Viçosa: UFV, 2011. 252p.

SAKOMURA, N.K.; ROSTAGNO, H.S. Métodos de pesquisa em nutrição de monogástricos. Jaboticabal: Funep, 2007. 283p.

SAS INSTITUTE. SAS/EST: User's guide. Version 8.2. Cary, 2001. 343p

SAW, N.K. et al. Effects of inositol hexaphosphate (phytate) on calcium binding, calcium oxalate crystallization and in vitro stone growth. Journal of Urology, v.177, p.2366-2370, 2007. Available from: $<\mathrm{http} / /$ www.sciencedirect.com/science/article/ pii/\%20S0022534707002510>. Accessed: Mar. 05, 2014. doi: 10.1016/jjuro.2007. 01.113.

SELLE, P.H.; RAVINDRAN, V. Phytate-degrading enzymes in pig nutrition. Livestock Science, v.p.113:99-122, 2008. Available from: <http://www.livestockscience.com/article/S18711413(07)00363-0/abstract>. Accessed: Dec. 12, 2013. doi: 10.1016/j.livsci.2007.05.014.

SELLE, P.H. et al. Phytate and phytase: enzymes. In: BEDFORD, M.R.; PARTRIDGE, G.G. (Eds.). Farm animals nutrition. Oxfordshire: CAB Intl,, 2011. p.164.

SERVI, S. et al. Dephytinisation of wheat bran by fermentation with bakers' yeast; incubation with barley malt flour and autoclaving at diferent $\mathrm{pH}$ levels. Journal of Cereal Science, v.48, p.471-476, 2008. Available from: $<\mathrm{http}: / /$ www.sciencedirect. com/science/article/pii/S0733521007002172>. Accessed: Apr. 22, 2014. doi: $10.1016 /$ j.jcs.2007.10.011.

SILVA, H.O. et al. Influência da fitase sobre a digestibilidade ileal aparente de aminoácidos em ingredientes para suínos na fase de crescimento. In: REUNIÃO ANUAL DA SOCIEDADE BRASILEIRA DE ZOOTECNIA, 42, 2005, Goiânia, GO. Anais... Goiânia: SBZ, 2005. V.42. 420p. p.236.

TRUJILLO, J.H.A.; LINDEMANN, M.D. Phosphorus utilization in growing pigs fed a phosphorus deficient diet supplemented with a rice bran product and amended with phytase. Revista Colombiana de Ciencias Pecuarias, v.23, p.429443, 2010. Available from: <http://www.scielo.org.co/scielo. php?pid $=$ S0120-06902010000400004\&script $=\quad$ sci_arttext $>$. Accessed: Feb. 07, 2014.

ZANELLA, I. et al. Effect of enzyme supplementation of broiler diets based on corn and soybeans. Poultry Science, v.78, p.561-568, 1999. Available from: <http://ps.oxfordjournals.org/ content/78/4/561.abstract>. Accessed: Dec. 06, 2013. doi: 10.1093/ ps/78.4.561. 